\title{
PIGMENTS CHARACTERIZATION OF MACROALGAE IN DRINI BEACH, GUNUNGKIDUL, YOGYAKARTA FOR SYSTEMATICS STUDY
}

\author{
Selvi Rahmawati, Riswi Haryatfrehni, Afra Meilianda, Matin Nuhamunada, Listia Pradani, \\ and Bagas Lantip Prakasa \\ Faculty of Biology Universitas Gadjah Mada, Yogyakarta, Indonesia \\ Email : rahmawatiselvi@gmail.com
}

\begin{abstract}
Drini Beach is one of beaches in Gunungkidul, D.I. Yogyakarta with dead-coral reefs as the landform. Dead-coral reef is a good habitat for macroalgae. Based on the pigment content, the macroalgae are divided into Chlorophyta, Phaeophyta, and Rhodophyta with their specific pigments chlorophyta, carotenoid and phycobiliprotein, respectively. These pigments are potentially used as a marker for identification and classification. The research aimed to identify and quantify pigments content of macroalgae in Drini Beach, Gunungkidul, DIY. Samples collection was done in June, 2013. Pigment extractions were done for polar and nonpolar pigments and then the extracts were analyzed using spectrophotometry UV-VIS Shimadzu Genesys 10. The result showed that nonpolar extraction of Chaetomorpha had a maximum absorption peak between 320-380, 400-500, and $670 \mathrm{~nm}$; Borgesenia has maximum peak of 340,440 , and $670 \mathrm{~nm}$; Cladophora in wavelenght of $340,415,435,470$, and $665 \mathrm{~nm}$; and Dictyosphaeria in wavelenght between 330-370, 415, 435, 470, and $665 \mathrm{~nm}$ of macroalgae samples; Padina in wavelenght of 340, 380, 440, 665 ; Gelidiella between 305-345 nm ; Gracilaria in wavelenght $330 \mathrm{~nm}$; Laurencia in wavelength between 310-340, 500, 550, 625 , and $680 \mathrm{~nm}$; and Amphiroa in wavelenght 330 dan $400 \mathrm{~nm}$. Besides, polar extraction using distilled water of Rhodhophyta showed maximum absorption peak of genus Gelidiella between 330-340, 410, and 665 nm; Gracilaria between 330-345, 410, 565, $665 \mathrm{~nm}$; Laurencia between 330-345, 435, and $665 \mathrm{~nm}$; and Amphiroa in wavelenght 335,415 , and $665 \mathrm{~nm}$. Based on the results, it could be concluded that Chlorophyta has chlorophyll a, b and carotenoid; Phaeophyta has chlorophyll a, b, and, c; and Rhodophyta has chlorophyll a, carotenoid, and phycoeritrine.
\end{abstract}

Key words :, macroalgae, Gunung Kidul, pigment, spectrophotometry

\section{INTRODUCTION}

Macroalgae is a Thallophyta which is potentially used as a bioindicator, source of alginate, gel, carageenan and natural pigment. Based on the pigment content in thallus, it can be divided into three division (Susanto, 2008). Generally, there are three main pigments in macroalgae, including chlorophyll, carotenoid, and phycobilline. Chlorophyll and carotenoid is nonpolar pigments which are not water soluble, besides phycobiline is polar pigment which are water soluble. Natural pigment usually useful for food suplement to optimize body metabolic system, immunity, detoxification, minimize inflamation and hormonal system balanced (Limantara, 2007). Chlorophyll can be used for stimulating blood synthesis (Anonim, 2008). Besides, carotenoid is main pigment which usuallay can easily found and can be synthesized by all photosynthetic organisms and fungi (Vilchez et al., 2011). Carotenoid can be divided into two groups, which are carotene and xanthophyll (Gross, 1991). Carotenoid also potential for natural sources of vitamin A, natural dye, erithrocyte stimulating, antioxidant, antibacterial, and immunity stimulating (Ndiha \& Limantara, 2009 ; Kusmiatiet al., 2010). Phycobilline can be divided into four groups, including phycoeritrobilline, phycocianobilline, phycoeritrocianine, and phycourobilline (Nobel, 2009). Phycobilline is usually observed in

ISSN 2413-0877 (C) 2015 The Authors.

Published by KnowledgeE Publishing Services This is an open access article under the CC BY-NC-ND license (http://creativecommons.org/licenses/by-nc-nd/4.0)

Selection and Peer-review under responsibility of the 3rd ICBS-2013

Doi http://dx.doi.org/10.18502/kls.v2i1.161 
red algae and can be extracted using water solvent (Masojidek et al., 2004). Generally, macroalgae pigments is a potential source of natural dye, cosmetics, and health. Moreover, pigment content is also one of the main indicator which is usually used for one of parameter in identification and classification in plant systematics. So far there is no complete and detalied information about spesific pigment in each of the macroalgae species. Drini Beach is one of Gunungkidul Beach that has dead coral reef as the landform. This kind of landform is a good habitat for macroalgae. This research aims to study the pigment profile and content in order to give more information for macroalgae identification and characterization in plant systematics.

For characterizing kinds of macroalgae pigment content from the extract, this research use reference (Table 1) in order to compare absorbance values from macroalgae extract with the absorbance value from the reference based on the other research.

Table 1. Character of peak pigment absorbance in photosynthetic pigments (Rabinowitch \& Govindjee, 1969)

\begin{tabular}{lll}
\hline \multicolumn{1}{c}{ Pigments } & \multicolumn{1}{c}{$\begin{array}{c}\text { Character of peak absorbance in } \\
\text { organic solvent } \\
(\mathrm{nm})\end{array}$} & \multicolumn{1}{c}{ Source } \\
\hline chlorophyll a & 420,660 & Photosynthetic organism (except bacteria) \\
chlorophyll b & 453,643 & Spermatophyta and green algae \\
chlorophyll c & 445,625 & Diatome and brown algae \\
chlorophyll d & 450,690 & Red algae \\
a-carotene & $420,440,470$ (hexana) & Leave, red algae and siphonales \\
B-carotene & $425,450,480$ (hexana) & Spermatophyta \\
Lutein & $425,445,475$ (ethanol) & Green algae, red algae \\
Violaxanthine & $425,450,475$ (ethanol) & Leave, brown algae \\
Fucoxanthine & $425,450,475$ (hexana) & Diatome and brown algae \\
Phycoerithrine & $490,546,576$ (aquadest) & Red algae dan cyanobacteria \\
Phycocianine & 618 (aquadest) & Red algae dan cyanobacteria \\
Allophycocianine & 654 (buffer phosfat pH 6,5) & Red algae dan cyanobacteria \\
\hline
\end{tabular}

\section{MATERIALS AND METHODS}

Macroalgae which is used in this research was taken from Drini Beach, Gunungkidul, DI Yogyakarta. Fresh macroalgae sample was taken from Chlorophyta, Phaeophyta and Rhodophya. The materials were sea sand, acetone $90 \%$, and aquadest. Sea sand was used for plant culture maceratation. Acetone was used for nonpolar pigment extraction, whereas aquadest was used for polar pigment extraction.

\section{Macroalgae Samples Preparation}

Macroalge sampling was done on June, 2013 in Drini Beach, Gunungkidul, DIY. Sample were commonly found in many Gunungkidul beaches. Macroalgae samples were saving in ziplock plastics, then it was brought into laboratorium. Samples was cleaned from ephyfit and other benthic organisms, then it was photographed and identificated. Extraction preparation was done by cleaning sea sand which would been used for plant culture maceration. Beside that, flacons for saving sample extracts were prepared and wrapped using alumunium foil. 


\section{Pigment extraction}

Extraction was done in the laboratorium with low light intencity and low room temperature. Nonpolar pigments extraction was used for Chlorophyta, Phaeophyta and Rhodophyta. Fresh macroalgae samples for each species which have been cleaned was weighed for five grams, it cutted into small pieces and put into mortar, then it added by two grams of sea sand and six $\mathrm{mL}$ cooled $90 \%$ acetone. It macerated for four minutes until the solution changed into green and dark red. Then, it poured into flacons. Five $\mathrm{mL}$ of cooled $90 \%$ acetone was poured into mortar, and then the rest of plant culture was macerated for three minutes until the solution changed into green and dark red again. After that, the rest solution was poured into the same flacon. To clarified the colour and prepared spectrophotometer, one $\mathrm{mL}$ extract was taken and sentrifugated for five minutes using the higesht speed in order to precipitated small particles. Pure extract was put into microtube then.

Polar pigment extraction was sone only for Rhodophyta. Fresh macroalgae samples which have been cleaned was weighed for five grams, it cutted into small pieces and put into mortar, then it added by two grams of sea sand and $10 \mathrm{~mL}$ cooled aquadest. It macerated for 3-4 minutes, the it added by $5 \mathrm{ml}$ cooled aquadest and macerated for 1-2 minutes more until the solution changed into red. The results was pour and filtered into flacon. To clarified the colour and prepared spectrophotometer, one $\mathrm{mL}$ extract was taken and sentrifugated for five minutes using the higesht speed in order to precipitated small particles. Pure extract was put into microtube then.

\section{Spectrophotometry Method}

Spectrophotometry method has been done in order to measure pigment absorbance in macroalgae samples extract. Before that, it was important to measure the blanko which are pure aquadest and acetone $90 \%$. The measured sample was the sentrifugated extracts and it was added by solute until limit marker on the kuvet and it was homogenized using micropipet. Spectrophotometer was adjusted for $300 \mathrm{~nm}$, then the blanko and samples extract in kuvets was measured for the absorbantion and adjusted until 0 . The procedure was repeated for wave lenght interval of $25 \mathrm{~nm}$ from $300 \mathrm{~nm}$ until $750 \mathrm{~nm}$. For each new wave lenght, it had to be calibrated using blanko. The absorbantion results was converted into graphics for analyzing based on the highest wave lenght which formed in each samples extract.

\section{RESULTS AND DISCUSSION}

Based, on Figure 1. It showed that Chaetomorpha and Dictyosphaeria have uncontinued graphic, it showed concentration of pigment extraction has high density, so that the absorbance value is too high. Peak absorbance of Chaetomorpha is between $320-380 \mathrm{~nm}$, between 400-500 nm, and $670 \mathrm{~nm}$. Peak absorbance of Borgesenia is 340, 440, and 670 $\mathrm{nm}$, eventhough the peak is lower than Chaetomorpha. There are also lower peak in wavelangth 415, 435, and $470 \mathrm{~nm}$. Cladophora has peak absorbance in 340, 415, 435, 470, and 665 nm. Dictyosphaeria has peak absorbance between 330-370, 415, 435, 470, and $665 \mathrm{~nm}$.. 


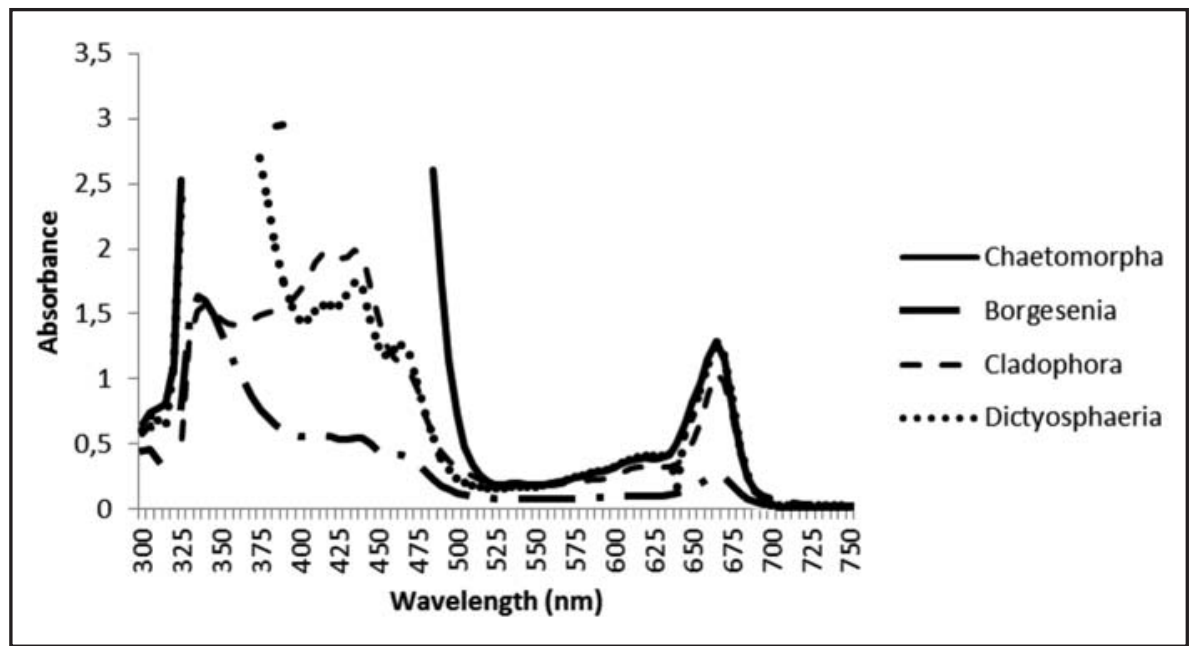

Figure 1. Spectrum absorbance of Chlorophyta extracted using acetone $90 \%$

Rhodophyta has polar and nonpolar pigments, so that this extraction using two kinds of solvent. Based on Figure 2. It showed that Laurencia and Pterocladia has uncontinued graphic. Peak absorbance of Pterocladia is between 305-345 nm. Peak absorbance of Gracilaria is $330 \mathrm{~nm}$. Laurencia has peak absorbance between 310-340, 500, 550, 625, and $680 \mathrm{~nm}$. Amphiroa has peak absorbance in 330 and $400 \mathrm{~nm}$.

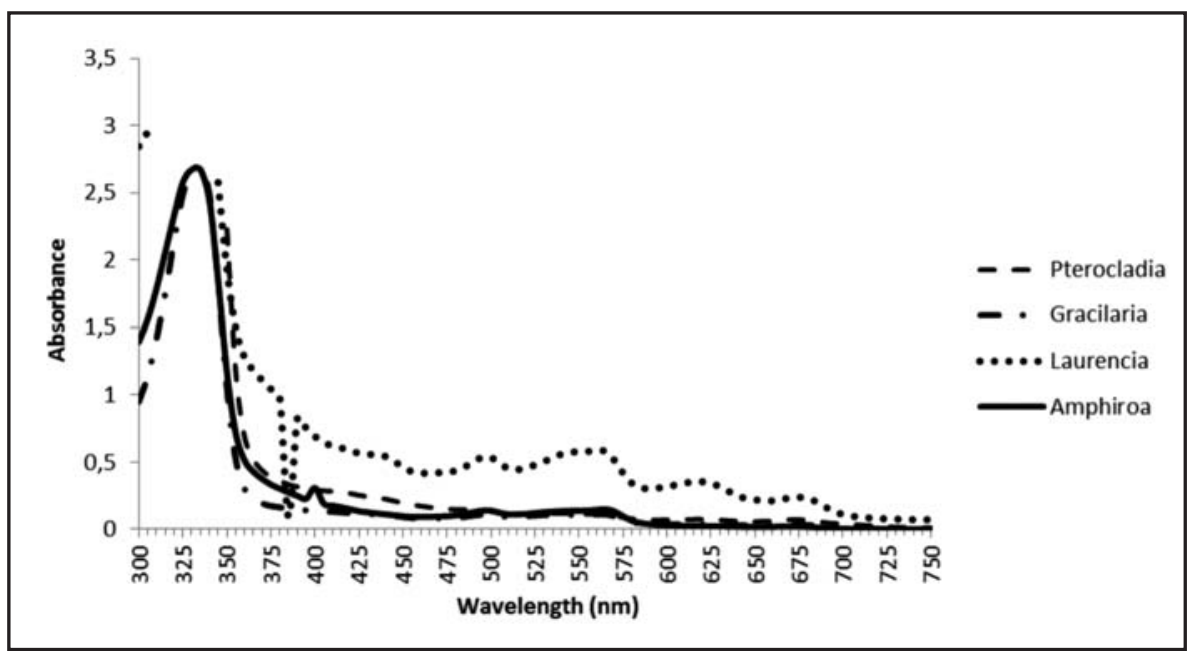

Figure 2. Spectrum absorbance of Rhodophyta extracted using aquadest

Based on Figure 3, it showed that Laurencia and Pterocladia has uncontinued graphic. Peak absorbance of Pterocladia is between 330-340, 410, and $665 \mathrm{~nm}$. Peak absorbance of Gracilaria is between 330-345, 410, 565, $665 \mathrm{~nm}$. Laurencia has peak absorbance between 330-345, 435, and $665 \mathrm{~nm}$. Amphiroa has peak absorbance in 335, 415, and 665 $\mathrm{nm}$.

Based on Figure 4., it showed that Padina sp. has peak absorbance of 340, 380, 440, and $665 \mathrm{~nm}$. 


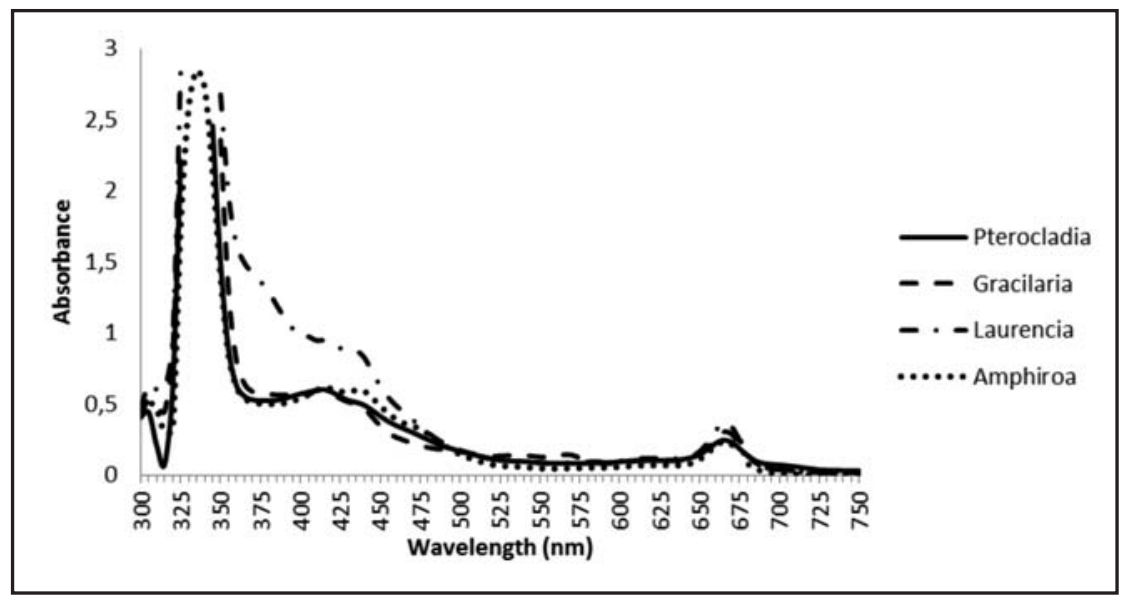

Figure 3. Spectrum absorbance of Rhodophyta extracte using acetone $90 \%$

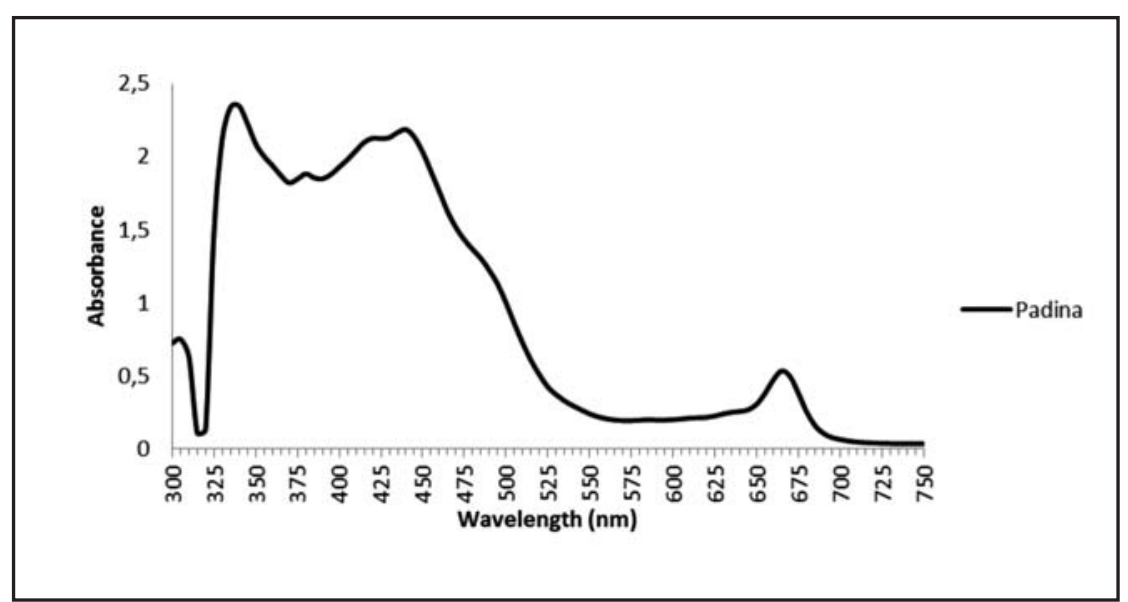

Figure 4. Spectrum absorbance of Phaeophyta extracted using acetone $90 \%$

The pigmentation of macroalgae samples can be classified into :

Table 2. Macroalgae pigmentation from the samples extract

\begin{tabular}{|c|c|c|c|c|}
\hline No & Division & Genus & Peak absorbance & Pigments \\
\hline 1 & \multirow{4}{*}{ Chlorophyta } & Chaetomorpha & $\begin{array}{l}\text { between } 320-380 \text {, between } 400-500 \text {, and } 670 \\
\text { nm }\end{array}$ & chlorophyll a, b, carotenoid \\
\hline 2 & & Borgesenia & 340,440, and $670 \mathrm{~nm}$ & Chlorohyll $\mathrm{a}$ and $\mathrm{b}$ \\
\hline 3 & & Cladophora & $340,415,435,470$, and $665 \mathrm{~nm}$ & $\begin{array}{l}\text { chlorophyll a, chlorophyll b, } \\
\text { carotenoid }\end{array}$ \\
\hline 4 & & Dictyosphaeria & between $330-370,415,435,470$, and $665 \mathrm{~nm}$ & chlorophyll a, b, carotenoid \\
\hline 5 & Phaeophyta & Padina & 340380440665 & $\begin{array}{l}\text { chlorophyll a, chlorophyll b, } \\
\text { and c }\end{array}$ \\
\hline \multirow[t]{2}{*}{6} & \multirow[t]{2}{*}{ Rhodophyta } & \multirow[t]{2}{*}{ Pterocladia } & between $305-345 \mathrm{~nm}$, & \multirow[t]{2}{*}{ chlorophyll a } \\
\hline & & & between 330-340, 410, and $665 \mathrm{~nm}$ & \\
\hline \multirow[t]{2}{*}{7} & & \multirow[t]{2}{*}{ Gracilaria } & $330 \mathrm{~nm}$ & \multirow[t]{2}{*}{ chlorophyll a, phycoeritrine } \\
\hline & & & between $330-345,410,565,665 \mathrm{~nm}$ & \\
\hline \multirow[t]{2}{*}{8} & & \multirow[t]{2}{*}{ Laurencia } & between $310-340,500,550,625$, and $680 \mathrm{~nm}$, & \multirow[t]{2}{*}{$\begin{array}{l}\text { phycoeritrine, chlorophyll a } \\
\text { carotenoid }\end{array}$} \\
\hline & & & between 330-345, 435, and $665 \mathrm{~nm}$ & \\
\hline \multirow[t]{2}{*}{9} & & \multirow[t]{2}{*}{ Amphiroa } & 330 and $400 \mathrm{~nm}$, & \multirow[t]{2}{*}{ chlorophyll a } \\
\hline & & & 335,415 , and $665 \mathrm{~nm}$ & \\
\hline
\end{tabular}




\section{CONCLUSION}

It can be concluded that Chlorophyta has chlorophyll $a, b$ and carotenoid; Phaeophyta has chlorophyll a, b, and, c; and Rhodophyta has chlorophyll a, carotenoid, and phycoeritrine.

\section{REFERENCES}

Kusmiati, N.W.S. Agustini, S.R. Tamat, and M. Irawati. 2010. Ekstraksi dan Purifikasi Senyawa Lutein Dari Mikroalga Chlorella pyrenoidosa Galur Lokal Ink. J Kimia Indonesia 5 : 3034

Limantara, L., and L. Kusmita. 2009. Biopigmen sebagai Antioksidan Potensial. Prosiding Seminar Nasional Farmasi, Antioksidan dalam Sediaan Obat, Kosmetika, Makanan dan Minuman. STIFAR Yayasan Farmasi. Semarang. P. 1-28

Ndiha, B.B.A., and L. Limantara. 2009. Karotenoid pada Bahan Makanan. Prosiding Seminar Nasional Biologi, Lingkungan dan Pembelajarannya. Jurdik Biologi. FMIPA Universitas Negeri Yogyakarta. P. 75-84

Nobel, PS. 2009. Physiochemical dan Environmental Plant Physiology. Academic Press. Canada. P. 582 